DEPARTMENT OF THE INTERIOR

UNITED STATES GEOLOGICAL SURVEY

PREPARED IN COOPERATION WITH THE

COMMONWEALTH OF MASSACHUSETTS

DEPARTMENT OF PUBLIC WORKS

\title{
AEROMAGNETIC MAP OF THE ASSAWOMPSET POND QUADRANGLE, PLYMOUTH AND BRISTOL COUNTIES, MASSACHUSETTS
}

GEOPHYSICAL INVESTIGATIONS

MAP GP-794

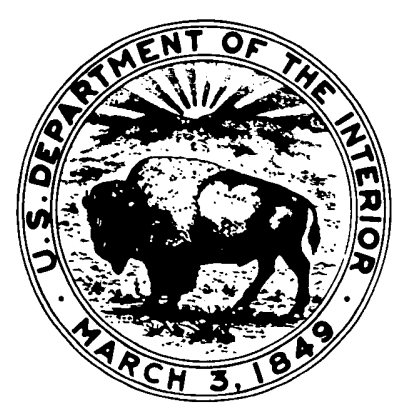

PUBLISHED BY THE U. S. GEOLOGICAL SURVEY

WASHINGTON. D.C. 20242 